\title{
Transport of Hexoses, Potassium and Neutral Amino Acids into Capillaries Isolated from Bovine Retina
}

\author{
A. Lorris Betz and Gary W. Goldstein \\ Departments of Pediatrics and Neurology, University of Michigan, \\ Ann Arbor, MI. 48109, U.S.A. \\ (Received 4 . June 1979 and in revised form 17 October 1979, New York)
}

\begin{abstract}
Capillaries were isolated from bovine retina by homogenization and glass bead filtration in order to study their ability to transport certain solutes. Viability of the microvessels was demonstrated by their ability to maintain linear rates of substrate oxidation for more than two hours. Hexose uptake (measured using 3-o-methyl-D-glucose) could be inhibited by uytodhalasin B, phloretin and phlorizin, but not by 2,4 -dinitrophenol or ouabain. $\nu$-Glucose, 2-deoxy-D-glucose, D-mannose, D-galactose and D-xylose inhibited 3-o-methyl-D-glucose uptake, while $\mathrm{L}$-glucose, $\mathrm{D}$-ribose and D-fructose did not. When incubated at $37^{\circ} \mathrm{C}$ with 5 mM-D-glucose, the microvessels entained much more free n-glucose than D-glucose metabolites. Thus, transport was not rate limiting for metabolism. L-Glucose entered capillaries more slowly than other hexoses and served as a marker for simple diffusion of sugars into the cells. ${ }^{86} \mathrm{Rb}+$ was used as an indicator of $\mathrm{K}+$ transport activity. Uptake of ${ }^{86} \mathrm{R} b^{+}$was temperature sensitive and markedly inhibited by $\mathrm{I}$ mM ouabain, thus indicating the presence of an active $\mathrm{K}+$ transport system. $\mathrm{Na}^{+}$-dependent amino acid transport was demonstrated using $\alpha$-(methylamino)isobutyric acid as a model substrate. Capillary uptake of this neutral amino acid analogue was inhibited after abolishing the $\mathrm{Na}^{+}$gradient with 1 mu-ouabain. Uptake of the organic anion $p$-aminohippuric acid (PAH) was slightly greater than uptake of the extracellular marker sucrose. There was a small inhibition of PAH uptake by fluorescein and penicillin but not by probenicid. Oux results indicate the presence. of several transport processes in retinal capillary endothelial cells which may be important for the maintenance of homeostasis within the retina.

Key words: glucose; 3-o-methylglucose; eytochalasin B; phloretin; phlorizin; glucose transport stereospecificity; rubidium; $\alpha$-(methylamino)-isobutyric acid; $p$-aminohippuric acid; endothelial cells; metabolism.
\end{abstract}

\section{Introduction}

The term "blood-retinal barrier" (BRB) is used to describe the selective exchange of certain solutes between blood and retina. This permeability barrier is thought to involve both restricted diffusion and carrier-mediated transport processes (CunhaVaz, 1976). Although there is considerable morphologic evidence indicating that both the capillary endothelium and the pigment epithelium of the retina are responsible for maintaining a normal BRB (Cunha-Vaz, 1976; Raviola, 1977), there is little information regarding their relative contributions. One approach to this problem is to sturly transport processes in preparations of pigment epithelium or retinal capillaries isolated from other cellular elements of retina. So far, there have been few investigations of this type.

The mechanism by which sugars move between the blood and retina is particularly important since D-glucose is a major metabolic substrate for the retina (Graymore, 1969) and because microangiopathy is an important component of diabetic retinopathy. Studies in vivo demonstrate that D-glucose uplake from blood to vitreous humor is stereospecific, thus implying a carrier-mediated mechanism (Dollery, Henkind and Orme, 1971). Using the isolated pigment epithelium from the frog; $0014-4835 / 80 / 050593+13 \$ 01.00 / 0$

(C) 1980 Academic Press Inc. (London) Limited 
Zadunaisky and Degnan (1976) observed net movement of sugars from choroidal to apical surfaces, however, in a similar preparation, Miller and Steinberg (1976) could not detect net sugar flux. There are no studies of D-glucose transport using isolated retinal capillaries.

There is considerable cvidence that ncutral amino acids (Reddy, Chakrapani and Lim, 1977a), potassium (Bito, 1970, 1977; Bito and Davson, 1964) and organie anions (Cunha-Vaz and Maurice, 1967) are actively transported out of the vitreous across the blood-retinal barrier but the cellular location of these active transport systems has been difficult to determine. Based on results of experiments in vivo, it has been suggested that amino acids arc transported only at the pigment epithelium (Reddy et al., 1977) while organic anions are transported at the capillary endothelium and the pigment epithelium (Cunha-Vaz and Maurice, 1967). However, it is difficult to interpret studies in which both BRB tissues are present. Direct evidence for active transport at the pigment epithelium has been presented by Miller and Steinberg $(1976,1977)$ and Lasansky and de Fisch (1966) who used the isolated frog pigment epithelium to demonstrate transport of ions, taurine and methionine. Recently, Hjelle, Baird-Lambert, Cardinale, Spector and Udenfriend (1978) described a nonenergy dependent transport system for large neutral amino acids in isolated retinal capillaries.

In this report, we describe some of the properties of hexose, small neutral amino acid, potassium and organic anion transport into isolated retinal capillaries. Our results suggest that transport of these solutes may occur at the microvascular component of the BRB.

\section{Materials and Methods}

Retinal capillaries were isolated by modification of methods previously described for use witl retina (Meezan, Brendel and Carlson, 1974) and brain (Goldstein, Wolinsky, Csejtey and Diamond, 1975). Bovine eyes were obtained from a local slaughterhouse and transported to the laboratory on ice. The globes were incised and the retinae were removed and placed in an iced buffer consisting of oxygen-saturated Ringer solution with $1 \cdot 2 \mathrm{mu}$ $\mathrm{MgCl}_{2}, 15 \mathrm{~mm}-N$-2-hydroxyethylpiperazine- $N^{\prime}$-2-ethanessulfonic acid (HEPES), $\mathrm{pH} 7 \cdot 4$, $1 \%$ fraction $\mathrm{V}$ bovine serum albumin and $5 \mathrm{~mm}$-sodium pyruvate. The retinae were washed extensively with buffer on a $335 \mu \mathrm{m}$ nylon mesh to remove small fragments of pigment epithelium. A $10 \%(\mathrm{w} / \mathrm{v})$ homogenate was made using 5 up-and-down strokes in a Teflon and glass homogenizer $(0.25 \mathrm{~mm}$ clearance) at $390 \mathrm{r} / \mathrm{min}$ and pelleted by centrifugation at $1000 \times \mathbf{g}$ for $10 \mathrm{~min}$. In order to obtain a uniform suspension of microvessels, the pellet was resuspended in a small amount of buffer and passed through a $335 \mathrm{~mm}$ nylun mesh. The capillaries were then separated from nuclei and other cellylar debris by passing the suspension through a $1.2 \times 1.5 \mathrm{~cm}$ column containing $0.25 \mathrm{~mm}$ glass beads. The capillaries were retained by the beads and were recovered by gentle agitation in buffer. After the beads settled, the supernatant was decanted and the capillaries were collected by centrifugation at $500 \times \mathbf{g}$ for 5 min. Cell protein was determined (Lowry, Rosebrough, Farr and Randall, 1951) after overnight solubilization in 1\% sodium dodecyl sulfate, using bovine serum albumin as the standard. The usual capillary yield was 0.17 $0.25 \mathrm{mg}$ of cell protein per retina.

The quality of each preparation was judged by its appearance under phase microscopy. Figure 1 shows a typical preparation which is largely free of contamination by nonvascular components. Occasional erythrocytes are seen trapped within the lumens of the microvessels. A few larger vessels were also secn. Contamination by erythrocytes was estimated by measuring the total hemoglobin content of the preparation using the method 


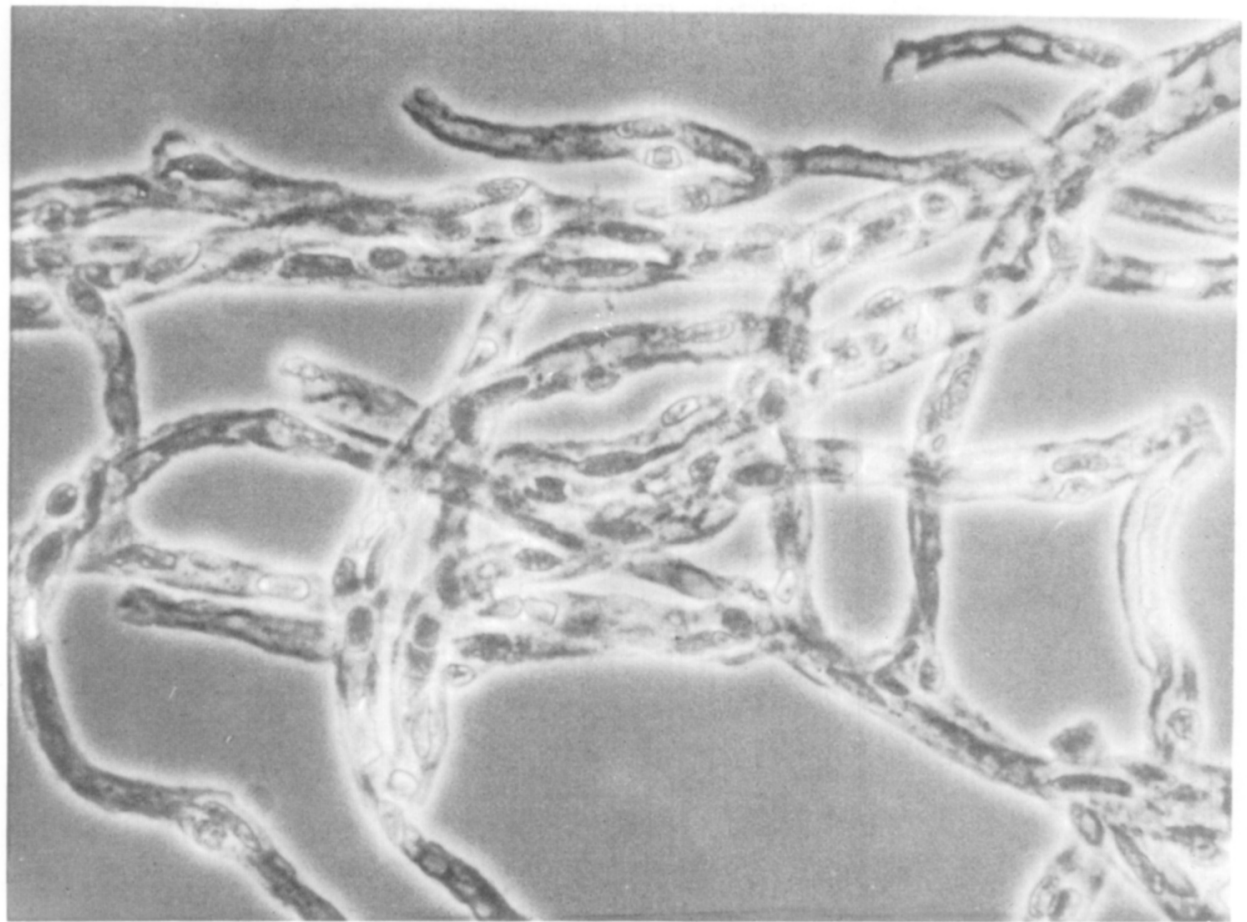

FIG. 1. Phase contrast photomicrograph of isolated retinal capillaries $(\times 450)$.

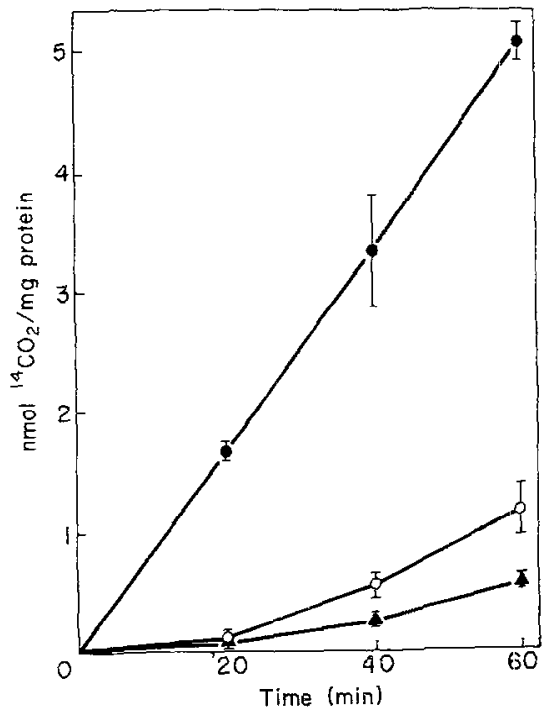

Fra. 2. Oxidative metabolism by isolated retinal vessels. $0-14 \mathrm{mg}$ of capillary protein were incubated at $37^{\circ} \mathrm{C}$ in a total volume of $3 \mathrm{ml}$ of buffer. The usual preparative buffer was used except that $1 \mathrm{mN}$ glucose was substituted for pyruvate and fatty acid free bovine serum albumin was used. Each incubation contained $2 \mu \mathrm{Ci}$ of ${ }^{14} \mathrm{C}$-labeled substrate and the flasks were flushed with $100 \% \mathrm{O}_{2} \cdot{ }^{14} \mathrm{CO}_{2}$ was trapped on filter papers saturated with $10 \% \mathrm{KOH}$. The reaction was terminated by the addition of $1 \mathrm{ml}$ of $1 \mathrm{~N} \cdot \mathrm{H}_{2} \mathrm{SO}_{4}$. The filters were removed and radioactivity determined in a liquid scintillation counter. - I ma [U-14 C]D-glucose; $0,0.15 \mathrm{~mm}\left[\mathrm{U}-{ }^{14} \mathrm{C}\right]$ palmitate; $\boldsymbol{A},\left[3{ }^{14} \mathrm{C}\right] \mathrm{D}-\beta$-hydroxybutyrate in $0.5 \mathrm{~mm}$ D.L- $\beta$-hydroxybutyrate. Data are the average of three determinations \pm s.D. 
of Hunter, Grove-Rasmussen and Soutter (1950). The resulting $27 \mu \mathrm{g}$ hemoglobin/mg total protein is equivalent to an intra-erythrocyte volume of $0.08 \mu \mathrm{l} / \mathrm{mg}$ protein.

The ability of isolated microvessels to oxidize glucose, palmitate, or $\beta$-hydroxybutyrate was measured by incubation at $37^{\circ} \mathrm{C}$ in the presence of ${ }^{14} \mathrm{C}$-labeled substrates (Goldstein, 1979). The ${ }^{14} \mathrm{CO}_{2}$ was trapped on filter papers saturated with $10 \% \mathrm{KOH}$. The isolated capillaries maintained a linear rate of $\mathbf{D}$-glucose oxidation for at least $1 \mathrm{hr}$ (Fig. 2). After a brief delay, the oxidation of palmitate and of $\beta$-hydroxybutyrate was also linear with time. These results confirm the metabolic integrity of isolated retinal capillaries (Meezan et al., 1974) and demonstrate their ability to utilize several different energy substrates normally present in the blood.

The melhod for measurement of sugar transport using glass fiber filters was identical to that deseribed previously (Betz, Csejtey and Goldstein, 1979). When indicated, $\left[{ }^{3} \mathrm{H}\right] \mathrm{p}$ glucose and its ${ }^{3} \mathrm{H}$-labeled products were separated by ion exchange chromatography (Lorenzo, 1976). As indicated in the figure legends, some experiments were performed at $25^{\circ} \mathrm{C}$ instead of $37^{\circ} \mathrm{C}$ in order to obtain a slower and more easily observable rate of transport. In experiments with ${ }^{86} \mathrm{Rb}^{+} 0.8 \mu \mathrm{m}$ microporous cellulosic filters (Amicon, Lexington, MA) were used instead of glass fiber filters to decrease filter blanks.

The following materials were obtained from New England Nuclear Corporation (Boston, $\mathrm{MA}): \quad\left[6-{ }^{3} \mathrm{H}\right] \mathrm{D}-\mathrm{glucose}, \quad\left[\mathrm{U}-{ }^{14} \mathrm{C}\right]_{\mathrm{D}-g l u c o s e}, \quad\left[\mathrm{methyl}^{3}{ }^{3} \mathrm{H}\right] 3-o-m e t h y l-\mathrm{D}-\mathrm{glucose}, \quad\left[\mathrm{U}^{-14} \mathrm{C}\right]-$ palmitic acid, $\left[3^{-14} \mathrm{C}\right] \mathrm{D}-\beta$-hydroxybutyric acid, $\left[1-{ }^{3} \mathrm{H}\right] \mathrm{L}-$ glucose, $\left[1-{ }^{14} \mathrm{C}\right] \alpha$-(methylamino)isobutyric acid, [glycyl-1-14 $\mathrm{C}] p$-aminohippuric acid, [U- $\left.{ }^{14} \mathrm{C}\right]$ sucrose, and ${ }^{86} \mathrm{Rb}+\mathrm{Cl}$. Phloretin. was purchased from $\mathrm{K} \& \mathrm{~K}$ Laboratories (Plainview, New York) and insulin from Eli Lilly and Company (Indianapolis, Indiana). All other chemicals were obtained from Sigma Chemical Company (St. Louis, Missouri).

\section{Results}

\section{Hexose transport and phosphorylation}

3-0-Methyl-D-glueose (3VG) was used as a model substrate for vharacterization of the D-glucose transport system. This sugar is nonmetabolizable (Czaky and Wilson. 1956) and has been used to study hexose transport by isolated brain capillaries (Betz et al., 1979). Figure 3 shows a time course for the uptake of 5 mM-3MG and its inhibition by 0.05 mm-cytochalasin B. The nontransported sugar L-glucose was used to measure the rate of simple diffusion into the preparation. Cytochalasin B is an inhibitor of D-glucose transport in several other cell systems including isolated brain capillaries (Betz et a1. 1979). In isolated retinal eapillaries it inhibited 3MG transport (Fig. 3) and reduced the initial uptake to nearly that of the diffusion marker. Contamination by erythrocytes did not significantly affect our results since the water space with which $3 \mathrm{MG}$ equilibrated $(4 \cdot 3 \mu \mathrm{l} / \mathrm{mg}$ protein) is much greater than the volume within the erythrocytes trapped in our preparation $(0.08 \mu \mathrm{l} / \mathrm{mg}$ protein).

The data in Table $\mathrm{I}$ show that phloretin and phlorizin were also effective inhibitors of sugar transport into isolated retinal microvessels. Phloretin was more effective than phlorizin, while cytochalasin B was the most potent inhibitor tested. We previously described an identical pattern for inhibition of sugar transport into isolated brain capillaries (Betz et al., 1979) and a similar pattern was observed at the blood-brain barrier in vivo (Betz, Drewes and Gilboe, 1975; Drewes, Horton, Betz and Gilboe, 1977). In contrast, $\mathrm{Na}^{+}$-dependent sugar transport in intestine and kidney is more sensitive to phlorizin than phloretin (Alvarado, 1967; Diedrich, 1966) and not inhibited by cytochalasin B (Hopfer, Sigrist-Nelson, Ammann and Murer, 1976). Further evidence that sugar transport into retinal capillaries is not energy or $\mathrm{Na}^{+}$- 


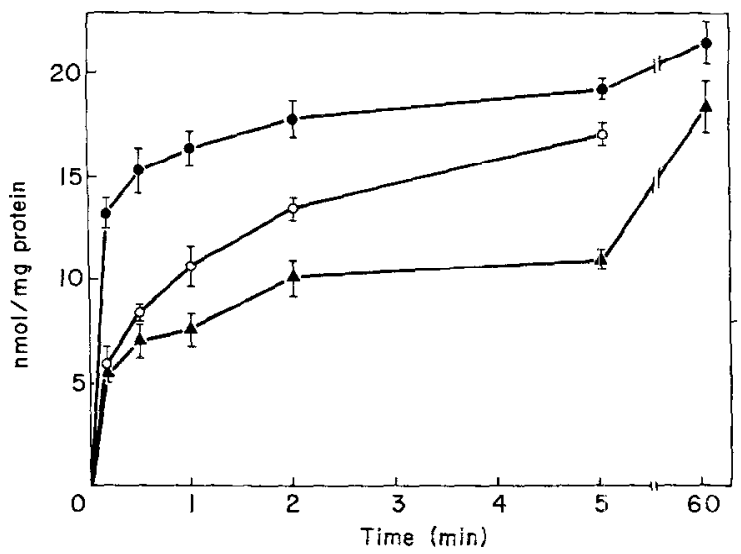

FIG. 3. Uptake at $25^{\circ} \mathrm{C}$ of $5 \mathrm{~mm}\left[{ }^{3} \mathrm{H}\right] 3-0$-methyl-D-glucose (๑), $5 \mathrm{~mm}\left[{ }^{3} \mathrm{H}\right]-3-o$-methyl-D-glucose inpresence of $0.05 \mathrm{~mm}$ cytochalasin $\mathrm{B}(\mathrm{O})$, and $5 \mathrm{~mm}\left[{ }^{3} \mathrm{H}\right] \mathrm{L}$-glucose $(\boldsymbol{\Delta})$. IData shown are averages of three determinations \pm S.D.

\section{TABLE I}

Effect of glucose transport inhibitors on 3-0-methyl-D-glucose uptake

\begin{tabular}{|c|c|c|c|}
\hline Inhibition & $\begin{array}{l}\text { Concentration } \\
(\mathrm{m} M)\end{array}$ & $\begin{array}{c}\text { Uptake } \\
(\mathrm{nmol} / \mathrm{mg} / 30 \mathrm{sec})\end{array}$ & $\begin{array}{l}\text { Percent } \\
\text { Control }\end{array}$ \\
\hline Cytochalasin B & 0.05 & $1 \cdot 68 \pm 0.68$ & 15 \\
\hline Phloretin & 0.50 & $5 \cdot 05 \pm 0 \cdot 37$ & 46 \\
\hline Phlorizin & 0.50 & $6 \cdot 69 \pm 1.11$ & 61 \\
\hline Control & - & $10 \cdot 88 \pm 0 \cdot 90$ & 100 \\
\hline
\end{tabular}

Uptake of $\left[{ }^{3} \mathrm{II}\right] 3 M G$ was determined after a 30 sce inoubation at $25^{\circ} \mathrm{C}$ in the presence of $5 \mathrm{mM} 3 \mathrm{MG}$ and the stated concentration of inhibitor. The data have been corrected for diffusion by using uptake of $\left[{ }^{3} \mathrm{H}\right] \mathrm{L}$-glucose determined in simultaneous incubations with $5 \mathrm{mu}-\mathrm{L}$-glucose $(5 \cdot 66 \mathrm{nmol} / \mathrm{mg} \mathrm{protein} /$ 30 sec \pm 0.58 s.D.). Values are the averages of 4 determinations \pm S.D.

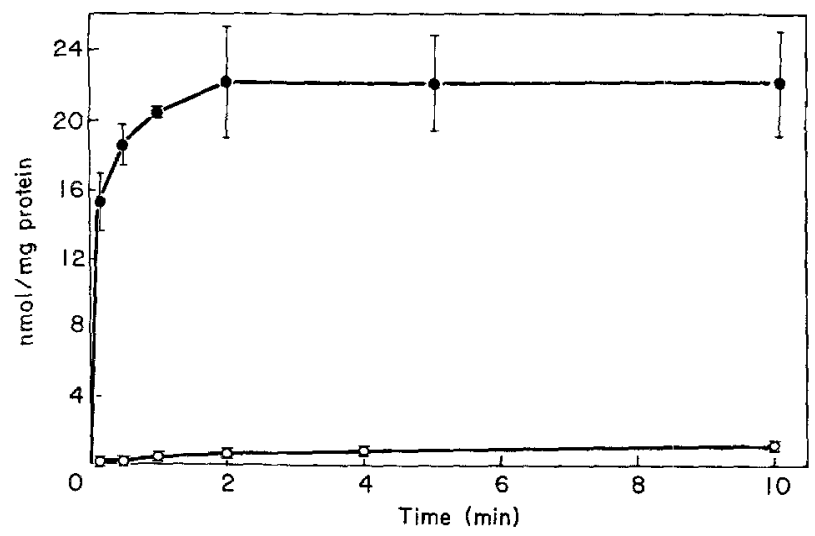

FIG. 4. Uptake and metabolism of $5 \mathrm{~mm}\left[{ }^{3} \mathrm{H}\right] \mathrm{D}$-glueose at $37^{\circ} \mathrm{C}$. After ineubation, intracellular radioactivity was separated into $\left[{ }^{3} \mathrm{H}\right] \mathrm{D}$-gincose $(\mathbf{O})$ and $\left[{ }^{3} \mathrm{H}\right] g$ lucose metabolites $(\mathrm{O})$ by ion-exchange chromatography, Data shown are averages of three determinations \pm s.D. 
Table II

Effect of possible modifiers of sugar transport on 3-0-methyl-n-glucose uptake

\begin{tabular}{lccc}
\hline \multicolumn{1}{c}{ Compound } & Concentration & $\begin{array}{c}\text { Uptake } \\
(\mathrm{nmol} / \mathrm{mg} / 30 \mathrm{sec})\end{array}$ & $\begin{array}{c}\text { Percent } \\
\text { Control }\end{array}$ \\
\hline & & & \\
Ouabain & $1.0 \mathrm{mM}$ & $6 \cdot 26 \pm 1 \cdot 29$ & 90 \\
2,4-Dinitrophenol & $0.5 \mathrm{mM}$ & $6 \cdot 70 \pm 1 \cdot 44$ & 97 \\
Insulin & $0.1 \mathrm{U} / \mathrm{ml}$ & $6 \cdot 34 \pm 0 \cdot 98$ & 91 \\
Control & - & $6 \cdot 94 \pm 0 \cdot 83$ & 100 \\
\hline
\end{tabular}

Isolated capillaries were proineubated for $30 \mathrm{~min}$ at $37^{\circ} \mathrm{C}$ in the presenee of the stated concentration of compound. Uptake of $\left[{ }^{3} \mathrm{H}\right] 3 \mathrm{MG}$ was then determined after a 30 sec incubation at $25^{\circ} \mathrm{C}$ in the presence of 5 mM-3MG. The data have been corrected for diffusion by using uptake of $\left[{ }^{3} \mathbf{H}\right] \mathrm{L}$-glucose determined in simultaneous incubations with $5 \mathrm{mM}$ L-glucose $(2.74 \mathrm{nmol} / \mathrm{mg}$ protein $/ 30 \mathrm{sec} \pm 0.22 \mathrm{s.D}$. $)$. Values are the iverages of 4 determinations \pm S.D.

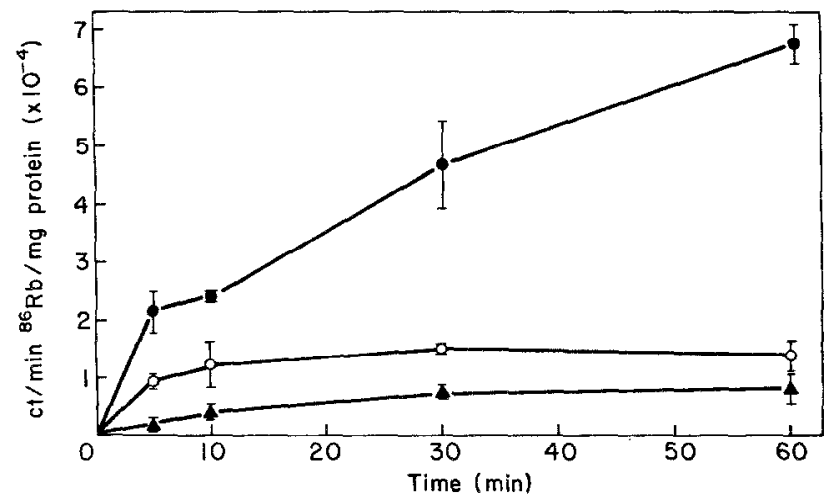

Frg. 5. Temperature dependent uptake of ${ }^{86} \mathrm{Rb}$ and inhibition by ouabain. Capillaries were incubated with $1.0 \times 10^{7}(\mathrm{et} / \mathrm{min}) / \mathrm{ml}$ of ${ }^{86} \mathrm{Rb}(\mathrm{SA}=82.3 \mu \mathrm{Ci} / \mu \mathrm{mol})$ at $(0) 37^{\circ} \mathrm{C},(\mathrm{O}) 37^{\circ} \mathrm{C}$ and 1 mM ouabain or (A) $4^{\circ}$ C. Data shown are averages of three determinations \pm S.D.

dependent is shown in Table II. There was no inhibition of 3MG uptake after a $30 \mathrm{~min}$ preincubation in the presence of $1 \mathrm{~mm}$-ouabain which eliminates the $\mathrm{Na}^{+}$gradient or 0.5 mM-2,4-dinitrophenol which depletes the supply of ATP. Sugar transport was not stimulated by insulin ('lable II).

It should be noted that values for glucose uptake under control conditions do vary from one preparation to another. However, within any individual preparation, the control uptake was constant and reproducible over the 1-2 hr that were required to complete the experiment. Therefore, data presented in each figure or table were obtained using a single capillary preparation, but the pattern of results could be reproduced on different preparations.

The stereospecificity of $3 \mathrm{MG}$ uptake was studied by measuring the uptake of $5 \mathrm{mM}-3 \mathrm{MG}$ in the presence of $100 \mathrm{mM}$ concentrations of various glueose analogues. Table III shows that D-glucose, 2-deoxy-D-glucose, 3-o-methyl-D-glucose, D-mannose, $\nu$-galactuse and $\mathrm{D}$-xylose were effective inhibitors of $3 \mathrm{MG}$ uptake, while $\mathrm{L}$-glucose, D-ribose and $D$-fructose were not. These results are nearly identical to those obtained in our previous study using isolated rat brain capillaries (Betz et al., 1979). Furthermore, the data justify use of $3 \mathrm{MG}$ as a measure of $\mathrm{D}$-glucose transport since $3 \mathrm{MG}$ 
uptake was markedly inhibited by D-glucose. Similarly, the lack of inhibition by $\mathrm{L}$ glucose supports use of this compound as a diffusion marker.

The relationship between the uptake of $D^{-g l u c o s e}$ and its subsequent metabolism is shown in Fig. 4. In the presence of $5 \mathrm{mM}-\mathrm{D}$-glucose and at $37^{\circ} \mathrm{C}$ transport was more rapid than metabolism and there was a large pool of free D-glucose within the cells. This relationship was also found in isolated brain capillaries (Betz et al., 1979) and would be required for efficient trans-endothelial movement of D-glucose from blood to retina or brain.

${ }^{86} R b^{+}$uptake

We used ${ }^{86} \mathrm{Rb}^{+}$to study $\mathrm{K}^{+}$transport into retinal capillaries. ${ }^{86} \mathrm{Rb}^{+}$has essentially identical transport properties in mammalian cells as $\mathrm{K}+$ (Vaughan and Cook, 1972) but has a longer half-life than radioactive potassium isotopes. Figure 5 shows the time course for uptake of a tracer concentration of ${ }^{86} \mathrm{Rb}^{+}$in the presence of $3 \mathrm{~mm}-\mathrm{K}^{+}$. This process was nearly eliminated at $4^{\circ} \mathrm{C}$ and was markedly inhibited by $1 \mathrm{~mm}$ ouabain. Ouabain sensitive uptake of $\mathrm{K}^{+}\left(\right.$or $\mathrm{Rb}^{+}$) is an energy dependent process

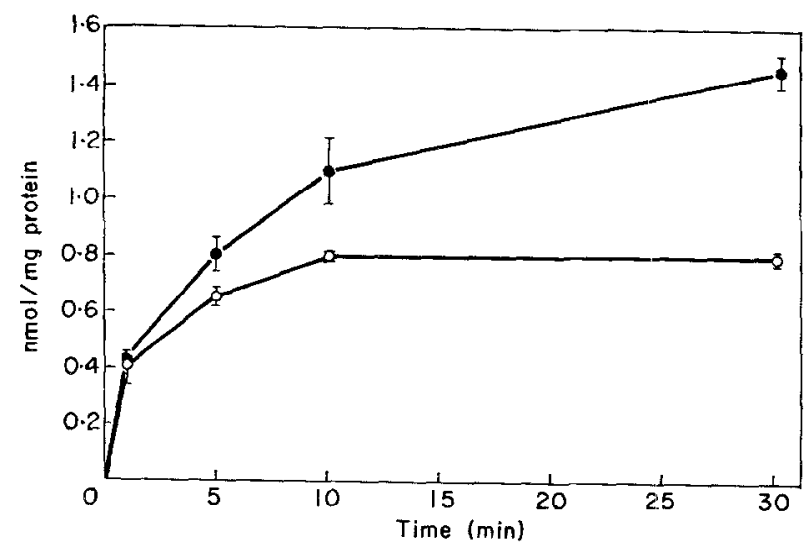

FIG. 6. Uptake of $\alpha$-(methylamino)isobutyric acid and inhibition by ouabain. Capillaries were preincubated for $30 \mathrm{~min}$ at $37^{\circ} \mathrm{C}$ with $(O)$ ol without $(O) 1 \mathrm{~mm}$ ouabain. Uptake of $0 \cdot 29 \mathrm{~mm}\left[{ }^{14} \mathrm{C}\right]-\alpha($ methylamino)-isobutyric acid was then determined. Data shown are averages of three determinations \pm s.D.

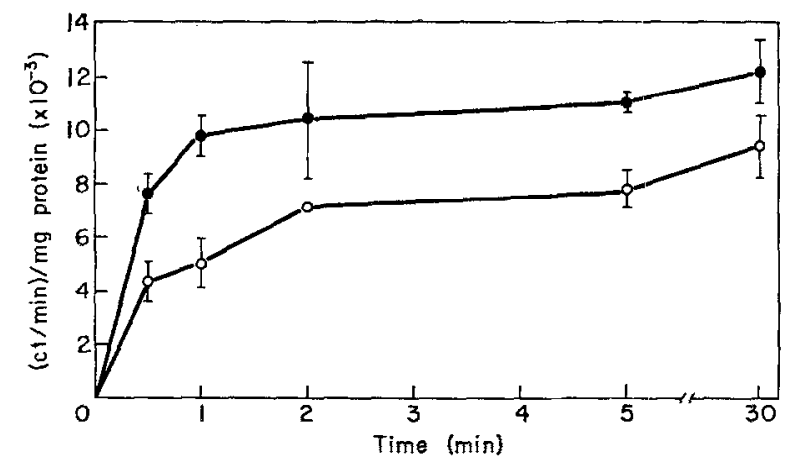

FrG. 7. Uptake of $p$-aminohippuric acid and sucrose. Capillaries were incubated at $37^{\circ} \mathrm{C}$ with $4.5 \times 10^{6}$ (ct/min) $/ \mathrm{ml}$ of $(0) 4 \cdot 5 \times 10^{-5} \mathrm{M}\left[{ }^{14} \mathrm{C}\right]-\mathrm{PAH}$ or $(\mathrm{O}) 3 \cdot 7 \times 10^{-6} \mathrm{M}\left[{ }^{14} \mathrm{C}\right]$ - sucrose and uptake determined. Data shown are averages of three determinations \pm S.D. 
TABLE III

Inhibition of 3-0-methyl-1-glucose uptake by glucose analogues

\begin{tabular}{|c|c|c|}
\hline Added sugar & $\begin{array}{c}\text { Uptake } \\
\text { (nmol/mg/30 sec) }\end{array}$ & $\begin{array}{l}\text { Percen } \\
\text { Contro }\end{array}$ \\
\hline D-Glucose & $2 \cdot 53 \pm 0.73$ & 38 \\
\hline 2-Deoxy-D-glucose & $3 \cdot 31 \pm 1.07$ & 50 \\
\hline B-o-Methyl-n-gluoose & $3 \cdot 39 \pm 0 \cdot 65$ & 51 \\
\hline D-Mannose & $3 \cdot 86 \pm 0.65$ & 58 \\
\hline D-Galactose & $4 \cdot 31 \pm 1 \cdot 31$ & 64 \\
\hline $\mathrm{b}-\mathrm{Xy}$ lose & $5 \cdot 37 \pm 1 \cdot 04$ & 81 \\
\hline $\mathrm{t}-\mathrm{Glucose}$ & $6.67 \pm 1.07$ & 100 \\
\hline D-Ribose & $6.69 \pm 0.67$ & 101 \\
\hline b-Fructose & $7 \cdot 19 \pm 0 \cdot 68$ & 108 \\
\hline Control & $6 \cdot 64 \pm 0.94$ & 100 \\
\hline
\end{tabular}

Uptake of $\left[{ }^{3} \mathrm{H}\right] 3 \mathrm{MG}$ was determined after a 30 see incubation at $25^{\circ} \mathrm{C}$ in the presence of $5 \mathrm{mu}-3 \mathrm{MG}$ and $100 \mathrm{~mm}$ inhibiting sugar. The control sample contained $100 \mathrm{~mm}$ mannitol to correct for osmotic effects. The data have been corrected for diffusion by using uptake of $\left[{ }^{3} \mathbf{H}\right] \mathrm{L}$-glucose in the presence of 5 mM Lglucose and $100 \mathrm{~mm}$ mannitol $(7.00 \mathrm{nmol} / \mathrm{mg} / 30 \mathrm{sec} \pm 0.60 \mathrm{s.D}$.). Values are the averages of 4 determinations \pm s.D.

mediated via $\mathrm{Na}^{+}, \mathrm{K}^{+}$-ATPase which exchanges intracellular $\mathrm{Na}^{+}$for extracellular $\mathrm{K}^{+}$. Thus a $\mathrm{Na}^{+}$gradient from outside to inside the cell is created and this gradient can be eliminated by ouabain. This property of ouabain was exploited in the following experiment.

\section{$N a^{\dagger}$-dependent amino acid uptake}

Transport of neutral amino acids into mammalian cells occurs via two distinct carrier systems (Christensen, 1973). One is $\mathrm{Na}^{+}$and energy dependent and prefers short-chain amino acids (A system), and the other is $\mathrm{Na}^{+}$and energy independent and prefers long-chain amino acids (L system). Hjelle et al. (1978) have previously described $\mathrm{Na}^{+}$-independent neutral amino acid transport in isolated retinal microvessels but could not demonstrate $\mathrm{Na}^{-}$-dependent uptake. We studied uptake of the non-metabolizable amino acid analog, $\alpha$-(methylamino)isobutyric acid ( $\alpha \mathrm{MeAIB})$ which is transported exclusively by the A system and has no affinity for the L system. Figure 6 shows a time course for uptake of $\alpha$ MeAIB into retinal capillaries. As expected for a $\mathrm{Na}^{+}$gradient dependent system, this uptake is inhibited by preincubation with ouabain. Thus, our results demonstrate the presence of an A system for neutral amino acid transport into isolated retinal capillaries. This transport system is capable of moving amino acids against a concentration gradient as long as a $\mathrm{Na}^{+}$gradient exists in the opposite direction.

\section{Uptake of p-aminohippuric acid ( $P A H)$}

Active transport of organic anions such as fluorescein (Cunha-Vaz and Maurice, 1967) and iodopyracet (Forbes and Becker, 1960) from retina to blood has been described. This process is inhibited by probenicid, an inhibitor of active PAH transport in the kidney, choroid plexus and ciliary body (Barany, 1973). Therefore, we 
TABLE IV

Effect of inhibitors on p-aminohippuric acid uptake

\begin{tabular}{|c|c|c|c|}
\hline Inhibitor & $\begin{array}{l}\text { Concentration } \\
\text { (mv) }\end{array}$ & $\begin{array}{c}\text { Uptake } \\
\left(10^{3} \mathrm{ct} / \mathrm{min} / \mathrm{mg}\right)\end{array}$ & $\begin{array}{l}\text { Percent } \\
\text { Control }\end{array}$ \\
\hline Control & & $13 \cdot 0 \pm 2 \cdot 7$ & 100 \\
\hline$p$-Aminohippuric acid & $10 \cdot 0$ & $12 \cdot 4 \pm 3 \cdot 3$ & 95 \\
\hline Probenicid & 0.5 & $13 \cdot 2 \pm 1 \cdot 7$ & 102 \\
\hline Fluorescein & $1 \cdot 0$ & $10 \cdot 3 \pm 1 \cdot 4: *$ & 80 \\
\hline Penicillin $\mathrm{G}$ & $10 \cdot 0$ & $9 \cdot 3 \pm 1 \cdot 4 \uparrow$ & 72 \\
\hline
\end{tabular}

\footnotetext{
Uptake was determined after 1 min incubation at $37^{\circ} \mathrm{C}$ in the presence of $0.045 \mathrm{mLM}\left[{ }^{44} \mathrm{C}\right] \mathrm{PAH}[4.8 \times$ $\left.10^{6}(\mathrm{ct} / \mathrm{min}) / \mathrm{ml}\right]$ and the stated concentration of inhibitor. Values are the averages of four determinations $\frac{1}{\perp}$ S.D. Results were compared to control using the Student's $t$-test.

$* P<0.05$

$+P<0 \cdot 01$
}

used PAH as a marker for organic anion transport into retinal capillaries. In Fig. 7 the rate of $\mathrm{PAH}$ uptake is compared to the rate of uptake of an extracellular marker, sucrose. PAH enters the microvessels more readily than sucrose and this may indicate the presence of a carrier-mediated transport system. However, the affinity of PAH for this transport system is apparently very low, since neither high concentrations of PAH nor: probenicid significantly decreased uptake of [ $\left.{ }^{14} \mathrm{C}\right] \mathrm{PAH}$ (Table IV). There is a small but significant inhibition of $\mathrm{PAH}$ uptake by fluorescein and penicillin $\mathrm{G}$. Hjelle et al. (1978) also found no effect of probenicid on PAH uptake by isolated. retinal capillaries.

\section{Discussion}

The term "blood-retinal barrier" is used to describe the limited retinal uptake of certain solutes from the plasma. However, some solutes, such as D-glucose (Dollery, Henkind and Orme, 1971) can easily enter the retina from the blood, while amino acids (Reddy et al., 1977) and organic anions (Cunha-Vaz and Maurice, 1967) appear to be actively excreted into the plasma across the BRB. Thus, the BRB should be considered to include both the limited permeability for some solutes and the carriermediated transport of others. The function of the BRB is to maintain a constant fluid and chemical environment in the retina.

Anatomically, both the capillary endothelial cells and the pigment epithelial cells contribute to the BRB (Cunha-Vaz, 1976). From in vivo studies it is often difficult to determine which component of the BRB contributes which function. One approach to this problem is to study solute transport processes in isolated tissues.

The isolated pigment epithelium from amphibians has been used to study transepithelial movements of ions (Lasansky and De Fisch, 1966; Steinberg and Miller, 1973; Miller and Steinberg, 1977), certain amino acids (Miller and Steinberg, 1976), and sugars (Miller and Steinberg, 1976; Zadunaisky and Degnan, 1976). Two contradictory reports on sugar fluxes have appeared. Zadunaisky and Degnan (1976) described unidirectional movement of $3 \mathrm{NG}$ from the choroidal to apical surface. This 
flux was inhibited by phlorizin and found only when there was a low electrical resistance across the isolated tissue. In contrast, Miller and Steinberg (1976) could find no net flux of $3 \mathrm{MG}$ and unidirectional fluxes were not saturable nor inhibitable by phlorizin. Similarly, ouabain inhibitable ion transport at the frog pigment epithelium has becn observed by some investigators (Miller and Steinberg, 1977) but not others (Lasansky and de Fisch, 1966). Thus, it is not clear whether transport of sugars or potassium occurs at the pigment epithelium.

Isolated retinal capillaries have been used in studies of substrate oxidation (Meezan et al., 1974), amino acid flux (Hjelle et al., 1978) and basement membrane composition (Mcozan, Hjclle and Brendel, 1975; Carlson, Brendel, Hjelle and Meezan, 1978). The preparation is metabolically active and thus appears to be an appropriate model for studies of the microvascular component of the BRB. However, it must be emphasized that these studies can only observe transport into the capillary cells and not across the capillary membranes, i.e. from lumen to the opposite side of the cell.

In the present report, we demonstrated the presence of hexose, neutral amino acid, and potassium transport systems in retinal microvessels. We have shown that hexose transport into these capillaries occurs by a stereospecific carrier-mediated transport system which can be inhibited by certain specific sugar transport inhibitors. Hexose transport in capillaries is not energy or $\mathrm{Na}^{+}$-dependent nor is it stimulated by high doses of insulin. Thus, this transport system is identical to the facilitated-diffusion type of $\mathrm{D}$-glucose transport system which is present in the blood-brain barrier (Betz, Gilboe and Drewes, 1976) and in isolated brain capillaries (Betz et al., 1979). DGlucose transport is very rapid compared to its metabolism in retinal capillaries and therefore the overall result is to promote equilibration of retinal $D$-glucose with the blood D-glucose. Thus, endothelial ecll metabolism would not normally impede the transport of $\mathrm{D}$-glucose across the capillary wall into the retina.

We have also demonstrated the presence of ouabain-inhibitable ${ }^{86} \mathrm{Rb}^{+}\left(\mathrm{K}^{+}\right)$and $\mathrm{Na}^{+}$ gradient dependent neutral amino acid transport systems. Although these transport systems are certainly not unique to endothelial cells, they may be particularly important as mechanisms for maintaining low $\mathrm{K}^{+}$and amino acid concentrations in the retina (Bito, 1970; 1977; Reddy et al., 1977). This could occur if $\mathrm{K}^{+}$and amino acids were transported from retina to blood against a concentration gradient. It is now apparent that brain capillary endothelial cells have a polar distribution of these transport systems between their two plasma membrane surfaces (Betz and Goldstein, 1978; Betz, Firth and Goldstein, 1980). Thus transport systems for $\mathrm{K}^{+}$and $\mathrm{A}$ system amino acids are not present in the luminal plasma membrane but are present in the antiluminal membranes. In contrast, hexose and $L$ system amino acid transport probably occur at both the luminal and antiluminal membranes. Polarity is maintained by the tight junctions which prevent intermixing of membrane proteins from the two sides of the cell (Staehelin and Hull, 1978). Furthermore, polarity permits brain capillaries to move solutes against transcellular concentration gradients. $\mathrm{By}$ analogy, the retinal capillary is probably also polar for $\mathrm{K}^{+}$and $\mathrm{A}$ system amino acid transport but not for glucose and L system amino acid transport. This arrangement should facilitate uptake of those nutrients which are required for normal retinal metabolism while allowing for pumping of selected solutes against a concentration gradient from retina to plasma. The action of these active transport systems should contribute to maintenance of a fixed concentration of ions and other solutes in the retina which otherwise might interfere with neural function. We emphasize that this model of the retinal capillary is speculative. Although compatible with in vivo 
transport data and histochemical studies using brain capillaries (Betz et al., 1980), it should be confirmed by histochemical studies using retinal capillaries.

The presence of active transport pumps in retinal capillaries suggests that this tissue has a high level of metabolic activity. This special property may contribute to the vulnerability of retinal capillaries to damage in the many disorders that produce retinal microangiopathy. A breakdown of the microvascular component of the BRB is one of the earliest detectable abnormalities in many retinal diseases including diabetic (Cunha-Vaz, Faria de Abreu, Campos and Figo, 1975), hypertensive (Garner, Ashton, Tripathi, Kohner, Bulpitt and Dollery, 1975), venous obstructive (Cunha$\mathrm{Vaz}, 1966$ ), ischemic (Cunha-Vaz, 1966; Cunha-Vaz and Shakib, 1967), and hyperviscosity (Wise, Dollery and Henkind, 1971) retinopathies. The causes for this breakdown are largely unknown. We feel that an important first step in understanding the pathogenesis of these disorders is to obtain more information about the normal properties of the retinal microvasculature.

\section{ACKNOWLEDGMENTS}

The authors thank J. Csejtey, A. Ste. Marie and R. Free for their excellent technical assistance. This work was supported by the National Foundation--March of Dimes and by Grants ES-02380 and HL-25492, postdoctoral followship NS-05807 (A. L. Betz) and Research Career Development Award NS-00278 (G. W. Groldstein) from the National Institutes of Health.

\section{REFERENCES}

Alvarado, F. (1967). Hypothesis for the interaction of phlorizin and phloretin with membrane carriers for sugars. Biochim. Biophys. Acta 135, 483-95.

Barany, E. H. (1973). The liver-like anion transport system in rabbit kidney, uvea, and choroid plexus. I. Selectivity of some inhibitors, direction of transport, possible physiological substrates. Acta Physiol. Scand. 88, 412-29.

Betz, A. L., Csejtey, J. and Goldstein, G. W. (1979). Hexose transport and phosphorylation by capillaries isolated from rat brain. Am. J. Physiol. 236, C96-C102.

Betz, A. L.; Drewes, L. R. and Gilboe, D. D. (1975). Inhibition of glucose transport into brain by phlorizin, phloretin and glucose analogues. Biochim. Biophys. Acta 406, 505-15.

Betz, A. L., Firth, J. A. and Goldstein, G. W. (1980). Polarity of the blood-brain barrier: Distribution of enzymes between the luminal and antiluminal membranes of brain capillary endothelial cells. Brain Res. in press.

Betz, A. L., Gilboe, D. D. and Drewes, L. R. (1976). The characteristics of glucose transport across the blood-brain barrier and its relation to cerebral glucose metabolism. In Transport Phenomena in the Nervous System (Eds Levi, G., Battistin, L. and Lajtha, A.). Pp. 133-49. New York, Plenum.

Betz, A. L. and Goldstein, G. W. (1978). Polarity of the blood-brain barrier: Neutral amino acid transport into isolated brain capillaries. Science 202, 225-27.

Bito, L. Z. (1970). Intraocular fluid dynamics I. Steady-state concentration gradients of magnesium, potassium and calcium in relation to the sites and mechanisms of ocular cation transport processes. Exp. Eye Res. 10, 102-16.

Bito, L. Z. (1977). The physiology and pathophysiology of intraocular fluids. In The Ocular and Cerebrospinal Fluids. Fogarty International Center Symposium (Eds Bito, L. Z., Davson, H. and Fenstermacher, J. D.). Exp. Eye Res. 25 Suppl., 273-89.

Bito, L. and Davson, H. (1964). Steady-state concentrations of potassium in the ocular fluids. Exp. Eye Res. 3, 283-97.

Carlson, E. C., Brendel, K., Hjelle, J. T. and Meezan, E. (1978). Ultrastructural and biochemical analyses of isolated basement membranes from kidney glomeruli and tubules and brain and retinal microvessels. J. Ultrastruc. Res. 62, 26-53. 
Christensen, H. N. (1973). On the development of amino acid transport systems. Fed. Proc. Fed. Am. Soc. Exp. Biol. 32, 19-28.

Cunha-Vaz, J. G. (1966). Studies on the permeability of the blood-relinal barrier LII. Bredkdown of the blood-retinal barrier by circulatory disturbances. A topographical study of the vaseular tree. Br. J. Ophthalmol. 50, 505-16.

Cunha-Vaz, J. G. (1976). The blood-retinal barriers. Doc. Ophthalmol. 41, 287-327.

Cunha-Vaz, J. G., Faria de Abreu, J. R., Campos, A. J. and Figo, G. M. (1975). Early breakdown of the blood-retinal barrier in diabetes. Br. J. Ophthalmol. 59, 649-56.

Cunha-Vaz, J. G. and Maurice, D. M. (1967). The active transport of fuorescein by the retinal vessels and the retina. J. Physiol. (London) 191, 467-86.

Cunha-Vaz, J. G. and Shakib, M. (1967). Ultrastructural mechanisms of breakdown of the bloodretina barrier. J. Path. Bact. 93, 645-52.

Czaky, T. Z. and Wilson, J. E. (1956). The fate of 3-o- ${ }^{14} \mathrm{CH}_{3}$-glueose in the rat. Biochim. Biophys. Acta 22, 185-6.

Diedrich, D. F. (1966). Competitive inhibition of intestinal glucose transport by phlorizin analogs. Arch. Biochem. Biophys. 117, 248-56.

Dollery, C. T., Henkind, P. and Orme, M. L'E. (1971). Assimilation of D and L 1-C-14 glucose into the retina, brain and other tissues. Diabetes 20, 519-21.

Drewes, L. R., Horton, R. W., Betz, A. L, and Gilboe, D. D. (1977). Cytochalasin B inhibition of brain glucose transport and the influence of blood components on inhibitor concentration. Biochim. Biophys. Acta 471, 477-86.

Forbes, M. and Becker, B. (1960). The transport of organic anions by the rabbit eye II. In vivo transport of iodopyracet (diodrast). Am. J. Ophthalmol. 50, 867-73.

Garner, A., Ashton, N., Tripathi, R., Kohner, E., Bulpitt, C. J. and Dollery, C. T. (1975). Pathogenesis of hypertensive retinopathy. An experimental study in the monkey. Br. J. Ophthalmol. $59,3-44$.

Goldstcin, G. W. (1979). Relation of potassium transport to oxidative metabolism in isolated brain capillaries. J. Physiol. (London) 286, 185-95.

Goldstein, G. W., Wolinsky, J. S., Csejtey, J. and Diamond I. (1975). Isolation of metabolically active capillarios from rat brain. $f$. Neurochern. 25, 715-7.

Graymore, C. N. (1969). General aspects of the metabolism of the retina. In The Eye (Ed. Davson, H.). Vol. 1, pp. 601-45. New York, Academic Press.

Hjelle, J. T., Baird-Lambert, J., Cardinale, G., Spoetor, S. and Udenfriend, S. (1978). Isolated microvessels: the blood-brain barrier in vitro. Proc. Nat. Acad. Sci. U.S.A. 75, 4544-8.

Hopfer, U., Sigrist-Nelson, K., Ammann, E. and Murer, H. (1976). Differences in neutral amino acid and glucose transport between brush border and basolateral plasma membrane of intestinal epithelial cells. J. Cell. Physiol. 89, 805-10.

Hunter, F. T., Grove-Rasmussen, M. and Soutter, L. (1950). A spectrophotometric method for quantitating hemoglobin in plasma or serum. Am. J. Clin. Path. 20, 12933.

Lasansky, A. and De Fisch, F. W. (1966). Potential, current, and ionic fluxes across the isolated retinal pigment epithelium and choroid. J. Gen. Physiol. 49, 913-24.

Lorenzo, A. V. (1976). The uptake and metabolism of $\mathrm{D}-\left[\mathrm{U}-{ }^{14} \mathrm{C}\right] \mathrm{glucose}$ by the choroid plexus. Brain Res. 112, 435-41.

Lowry, O. H., Rosebrough, N. J., Farr, A. L. and Randall, R. J. (1951). Protein measurement with the Folin phenol reagent. J. Biol. Chem. 193, 265-75.

Neezan, E., Brendel, K. and Carlson, E. C. (1974). Isolation of a purified preparation of metabolically active retinal blood vessels. Nature (London) 251, 65-7.

Meezan, E., Hjelle, J. T. and Brendel, K. (1975). A simple, versatile, non-disruptive method for the isolation of morphologically and chemically pure basement membranes from several tissues, Life Sci. 17, 1721-32.

Miller, S. and Steinberg, R. H. (1976). Transport of taurine, L-methionine and 3-O-methyl-D- 
Staehelin, L. A. and Hull, B. E. (1978). Junctions between living cells. Sci. Am. 238, 141 $\sim 52$.

Steinberg, R. H. and Miller, S. (1973). Aspects of electrolyte transport in frog pigment epithelium. Exp. Eye Res. 16, 365-72.

Vaughan, G. L. and Cook, J. S. (1972). Regeneration of cation-transport capacity in HeLa cell membranes after blockade by ouabain. Proc. Nat. Acad. Sci. L.S.A. 69, 2627-31.

Wise, G. N., Dollery, C. T. and Henkind, P. (1971). The Retinal Circulation. Pp. 392-9. New York, Harper and Row.

Zadunaisky, J. A. and Degnan, K. J. (1976). Passage of sugars and urea across the isolated retina pigment epithelium of the frog. Exp. Eye Res. 23, 191-6. 